\title{
PRIMENA LABVIEW PROGRAMSKOG PAKETA ZA KONTROLU I PRAĆENJE PROCESA RADA STANICE ZA PREKUGLAVANJE BGAČIPOVA
}

\author{
Milan Radivojevići \\ Miša Stević2 \\ Marko Tanasković ${ }^{3}$
}

${ }^{1}$ Institut za rudarstvo i metalurgiju Bor, Bor, Srbija ${ }^{2}$ Mikroelektronika d.0.0,

Beograd, Srbija

UUniverzitet Singidunum,

Beograd, Srbija

\section{Rezime:}

Cilj ovog rada je da se ispita primena LabVIEW programskog paketa za kontrolu i praćenje procesa rada uređaja, stanice za prekuglavanje BGA (eng. Ball Grid Array) čipova. Proces prekuglavanja je složen proces i obuhvata više faza. Uređaj je konstruisan u Boru, izvršeno je njegovo testiranje i utvrđene su njegove osnovne karakteristike.

\section{Ključne reči:}

Računarski sistem, virtualni instrument, prekuglavanje, akvizicija, LABView.

\section{UVOD}

Prekuglavanje BGA čipova je složen proces i u osnovi obuhvata sledeće postupke: a) odvajanje čipa sa ploče na kojoj se nalazi, b) skidanje starog lema sa ploče i čipa, c) priprema ploče i čipa, nanošenje novog materijala (postavljanje novih lemnih kuglica) na čipu i spajanje čipa sa štampanom pločom.

Danas postoji veliki broj uređaja (stanica) koji se koriste za prekugavanje BGA čipova. Osnovni delovi takvih uređaja su: nosač (podloga) na koji se postavlja štampana ploča sa BGA čipom koga treba odvojiti od nje, grejači - vrše zagrevanje ploče i čipa, kontroleri temperature donje i gornje površine ploče, senzor temperature čija je uloga praćenje, odnosno očitavanje temperature, kako ne bi došlo do pregrevanja BGA čipa, odgovarajući prekidači i drugi. Ovaj rad predstavlja, odnosno obrađuje, jedan ovakav uređaj koji je baziran na LabVIEW programskom paketu za kontrolu i praćenje njegovog rada.

Rad sadrži tri celine. U prvoj celini date su osnovne hardverske karakteristike uređaja, stanice. Druga celina obuhvata hardversku strukturu i programsku podršku za merenje, akviziciju podataka i za kontrolu i praćenje procesa prekuglavanja BGA čipova. Treća celina sadrži pregled postupaka eksperimentalnog snimanja karakteristika stanice. e-pošta:

mdradivojevic@gmail.com 


\section{OSNOVE KARAKTERISTIKE STANICE ZA PREKUGLAVANJE BGA ČIPOVA KONSTRUISANE U BORU}

Osnovni delovi uređaja, odnosno stanice za prekuglavanje BGA čipova, koji je konstruisan u Boru prikazani su na Slici 1. Uređaj sadrži dva grejača. Donji se nalazi sa donje strane aluminijumske podloge na kojoj su pričvršćeni nosači štampane ploče koju je potrebno zagrevati. Donji grejač je bez duvaljke i smešten je u oklopljenom kućištu neposredno ispod aluminijumske ploče. Drugi, gornji grejač je pokretan i poseduje ventilator. Podešavanje visine i pozicije grejača vrši se uz pomoć step motora i mehanizma sa navojnom šipkom. Donji grejač greje veću površinu štampane ploče čime se onemogućava da gornji grejač stvara veliku razliku u temperaturi gornje i donje strane čipa, integralnog kola, ili neke druge komponente. Oba grejača kontrolišu se PWM signalnom (eng. Pulse Width Modulation [1]). Za kontrolu grejača korišćeni su trijaci sa potrebnim perifernim sklopom za povezivanje sa A/D (analog to digital) konvertorom. Napajanje grejača vrši se pomoću naizmeničnog napona $220 \mathrm{~V}$ i oni su, preko odgovarajućeg transformatora, galvanski izolovani od mrežnog napajanja (220V).

Merenje temperature vrši se pomoću dva NiCr-Ni termopara čiji su signali pojačani operacionim pojačavačima. Pri maksimalnoj temperaturi na izlazu operacionog pojačavača dobija se signal amplitude $10 \mathrm{~V}$, što je maksimalni opseg merenja A/D konvertora. Time je ostvarena maksimalna preciznost i minimalna greška merenja.

U kućištu stanice smešteni su kompletan elektronski sklop i napajanje elektronskih uređaja i grejača. S obzirom na to da se pri prekuglavanju čipova radi sa relativno visokim temperaturama (preko $200{ }^{\circ} \mathrm{C}$ ), sve elektronske komponente instalirane su po samoj ivici uređaja kako bi bile što više udaljene od donjeg grejača. Između njih i grejača postavljena je kamena vuna koja obezbeđuje dodatnu toplotnu izolaciju. Merna kartica i računar, sa kojim je povezana, su u slučaju proboja trijaka ili havarije grejača posebno zaštićeni odgovarajućim optokaplerima.

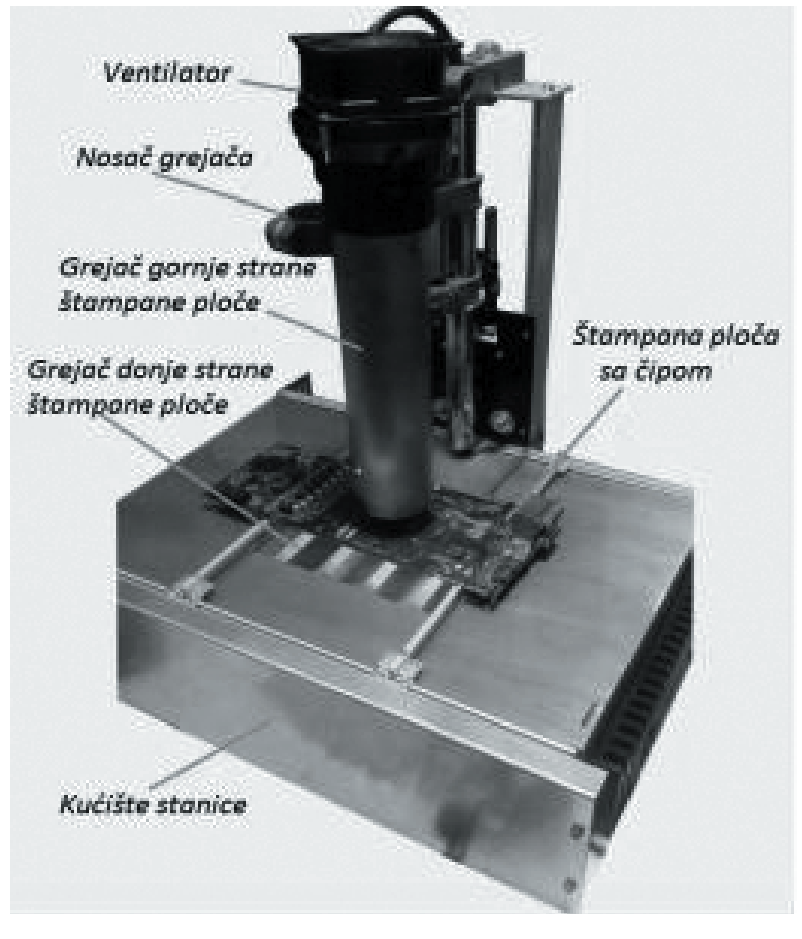

Slika 1. Stanica u režimu operativnog rada

Za potrebe akvizicije podataka upotrebljen je komercijalno dostupan A/D - D/A konvertor (akviziciona kartica) NI USB-6009. Uz NI USB-6009 dostavljen je i skup posebnih drajvera koji omogućava povezivanje mernokontrolnog uređaja (stanice) sa programskim paketom LabVIEW koji predstavlja industrijsko, programsko i razvojno okruženje, odnosno platformu, namenjenu kreiranju aplikacija za prikupljanje i automatsko evidentiranje podataka, testiranje, kontrolu instrumenata, kao i za različita merenja i upravljanja procesima[2],[3].

\section{HARDVERSKA STRUKTURA SISTEMA ZA MERENJE I AKVIZICIJU PODATAKA}

Sistem za merenje i akviziciju podataka sastoji se iz dva modula: hardverskog i softverskog, kao i dodatne opreme koja se koristi za međusobno povezivanje hardverskih delova[4],[5],[6]. Na Slici 2 šematski je prikazana funkcionalna struktura sistema za merenje i akviziciju podataka. Električni signali koji se dobijaju na izlazu senzora obično imaju relativno male vrednosti (na primer, napon na izlazu termopara ima vrednosti u intervalu $0-50 \mathrm{mV}$ ), pa se zbog toga dalje vode na ulaz odgovarajućeg pojačavača. Tako pojačan signal dovodi se na ulaz A/D konvertora gde se transformiše u digitalni električni signal (podaci o vrednostima signala), a potom, u tom obliku, na ulaz PC računara. 


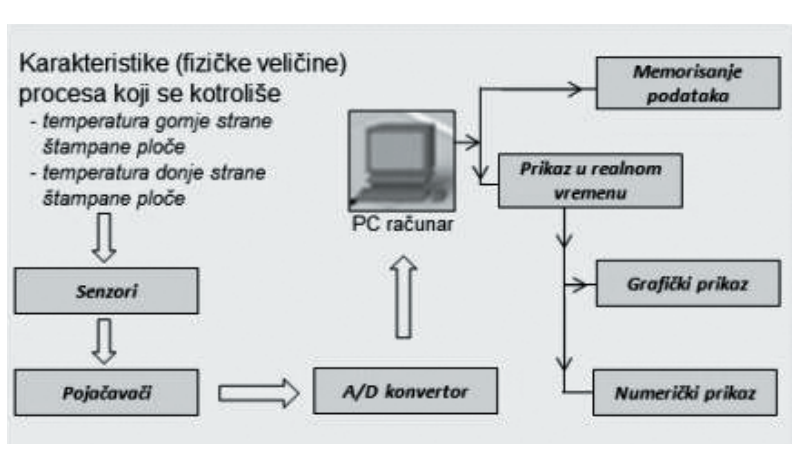

Slika 2. Šematski prikaz funkcionalne strukture sistema za merenje i akviziciju podataka

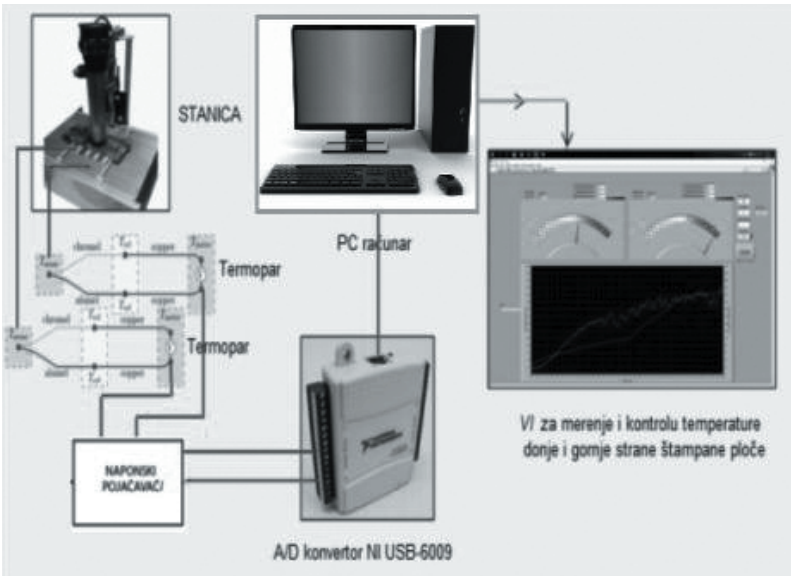

Slika 3. Model akvizicijskog i merno-kontrolnog sistema (uređaja) za prekuglavanje čipova razvijen i konstruisan u Boru

U PC računaru podaci se, upotrebom odgovarajućeg sofrvera, obrađuju i dobijeni rezultati memorišu i/ ili se vrši njihov prikaz bilo u grafičkom, ili numeričkom obliku. Grafički ili numerički prikaz izlaznih rezultata omogućava praćenje i kontrolu aktuelnog procesa.

Na Slici 3 prikazan je model akvizicijskog i mernokontrolnog sistema (uređaja-stanice) za prekuglavanje čipova razvijen i konstruisan u Boru. Osnovne karakteristike A/D konvertora, odnosno NI USB-6009 kartice[7] date su u Tabeli 1.

\section{PROGRAMSKA PODRŠKA SISTEMU ZA MERENJE I AKVIZICIJU PODATAKA}

Pored neophodnih hardverskih komponenata, funkcionisanje savremenih sistema za akviziciju podataka ne može se zamisliti bez primene odgovarajuće softverske podrške. Za realizaciju softvera za akvizicione sisteme koji su podržani PC računarima postoji više načina[8]. Mi smo se, kada je reč o sistemu čiji je model prikazan na Slici 3, opredelili za izradu softvera korišćenjem programskog paketa LabVIEW, koji predstavlja na određen način standard $\mathrm{u}$ oblasti softvera za virtualnu instrumentaciju.

Virtualna instrumentacija predstavlja metodologiju za projektovanje instrumenata koja koristi PC računar i posebne hardverske komponente za akviziciju podataka, digitalnu konverziju signala i računarske programe koji omogućavaju prikupljanje podataka, obradu i prikaz dobijenih rezultata na računaru. U osnovi, to je spoj hardverskih i softverskih elemenata kojima se ostvaruje funkcija klasičnog instrumenta.

\begin{tabular}{lc}
\hline \multicolumn{1}{c}{ Karakteristike } & Vrednosti \\
\hline broj ulaznih analognih kanala (AI) & 8 \\
\hline broj izlaznih analognih kanala (AO) & 2 \\
\hline opseg ulaznog napona & $\pm 10 \mathrm{~V}$ \\
\hline opseg izlaznog napona & $0-5 \mathrm{~V}$ \\
\hline broj digitalnih ulaza/izlaza & 12 \\
\hline broj bitova AD konverzije & 14 \\
\hline broj bitova DA konverzije & 12 \\
\hline nelinearnost pojačanja & $0,024 \%$ \\
\hline
\end{tabular}

Tabela 1. Karakteristike NI-USB-6009

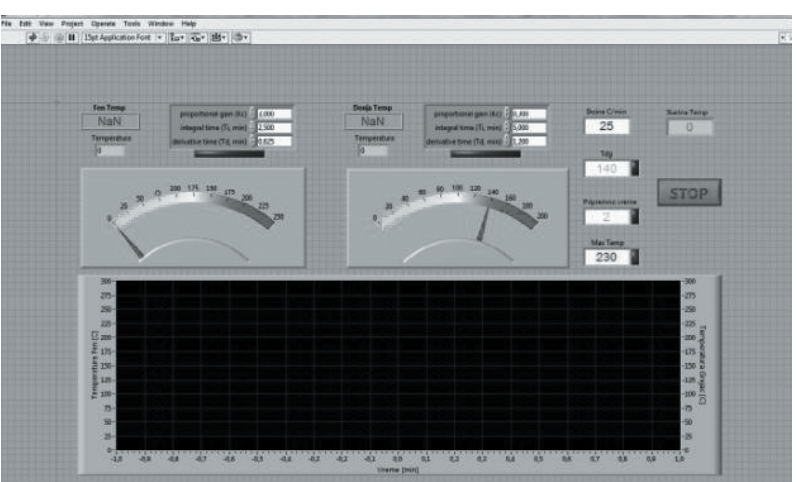

Slika 4. Prednja ploča virtuelnog instrumenta za kontrolu i praćenje rada stanice za prekuglavanje čipova konstruisane u Boru

Virtualni instrument (VI) za svaku mernu metodu sastoji se iz prednje ploče i blok dijagrama.

Prednja ploča je grafički korisnički interfejs instrumenta i sadrži odgovarajuće vizuelne elemente preko kojih korisnik učestvuje u procesu merenja i kontrole, 
odnosno zadaje parametre procesa i prati dobijene rezultate. Izgled i sadržaj prednje ploče VI koji se koristi za praćenje i kontrolu rada stanice prikazani su na Slici 4. U desnom gornjem uglu prednje ploče (Slika 5) nalazi se celina kontrola i četiri indikatora: (Startna Temp) koji nam na početku procesa praćenja pokazuje vrednost sobne temperature i tri indikatora koji, kada se ispune određeni uslovi u toku rada, zasvetle. $\mathrm{U}$ ovom delu nalazi se i dugme - kontrola STOP - čija je funkcija prekid rada VI.

Na prednjoj ploči virtuelnog instrumenta takođe su smeštene kontrole (Slika 6) za unos i ažuriranje vrednosti koeficijenata PID (proportional-integral-derivative controller) kontrolera za stabilizaciju temperature donjeg i gornjeg grejača i crtanje grafika zavisnosti temperature od vremena. Podešavanje PID-a je dosta složen posao jer zahteva da oscilacije temperature oko već zadatih vrednosti (primera radi: $140^{\circ} \mathrm{C}$ za donji i $230^{\circ} \mathrm{C}$ za gornji grejač) budu što manje i da traju što kraće kako ne bi došlo do pregrevanja ploče ili čipa.

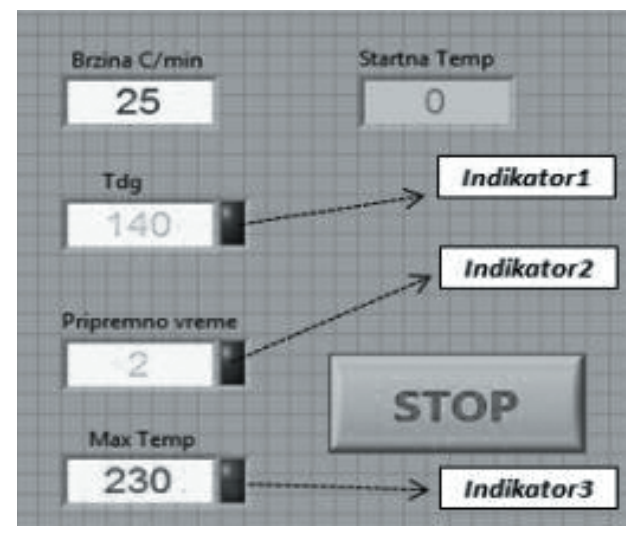

Slika 5. Sadržaj desnog gornjeg ugla prednje ploče VI
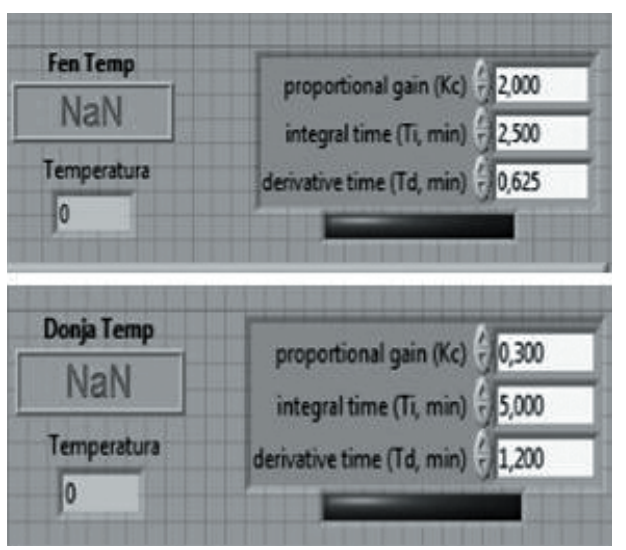

Slika 6. Unos i ažuriranje koeficijenata PID kontrolera gornjeg grejača

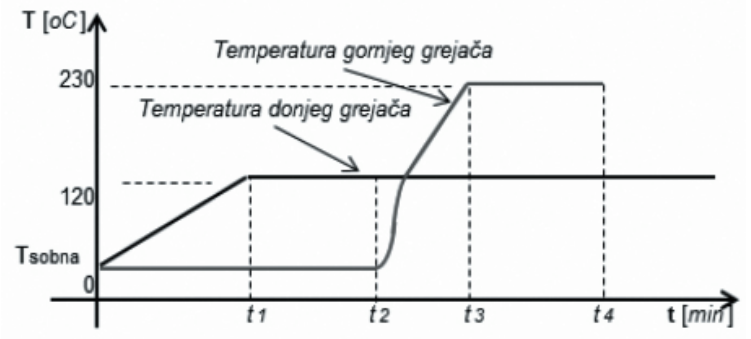

Slika 7. Zavisnost temperature gornjeg $i$ donjeg grejača od vremena

Virtuelni instrument je koncipiran tako da omogućava očitavanje i praćenje vrednosti temperatura grejača gornje i donje strane štampane ploče (na Slici 4 indikatori sa pokretnom iglom) sa koje se skida postojeći, ili na kojoj se postavlja novi čip. Kontrola i praćenje počinju pritiskom na taster Run, a završava se pritiskom na dugme STOP, koji se nalazi na prednjoj ploči VI. Pre početka novog praćenja potrebno je obrisati postojeće podatke sa dijagrama.

Kontrola i praćenje rada uređaja odvijaju se u skladu sa dijagramom prkazanim na Slici 7. Naime, nakon pritiska tastera Run na uređaju se uključuje donji grejač čija se temperatura postepeno povećava do oko $120^{\circ} \mathrm{C}$, a zatim se na dalje održava na toj vrednosti. $U$ trenutku t2 uključuje se gornji grejač (fen), koji je do tada bio na sobnoj temeperaturi. Njegova se temperatura, u periodu od $\Delta t=t 2-t 3$, povećava do temperature topljenja kuglica kalaja (temperatura topljenja kalaja je $231,93{ }^{\circ} \mathrm{C}$ ) [9] i ta se vrednost održava $t 4-t 3$ minuta za koje vreme kuglice kalaja postepeno prelaze iz čvrstog u tečno stanje. U momentu $t 4$ isključuje se gornji grejač i automatski se uključuje step motor koji pomera grejač na veću visinu. Po podizanju gornjeg grejača na odgovarajuću visinu pritisne se dugme STOP čime se uređaj isključuje, a čip se, pincetom, ili nekim drugim alatom, skida (odvaja) sa štampane ploče. Nakon što se čip odvoji od ploče pristupa se otklanjanju, odnosno skidanju, starih lemnih kuglica mašinom za skidanje kalaja, lema, ili na drugi način, sa čipa, koje su tokom rada izgubile osobine neophodne za ostvarivanje kvalitetnog kontakta i zaostalog lema na ploči. Čip se potom premaže specijalnom pastom (fluks) da bi se što boje očistio. Takođe se, korišćenjem posebnih hemijskih sredstava, očisti što je moguće bolje i deo na štampanoj ploči gde stoji čip. 


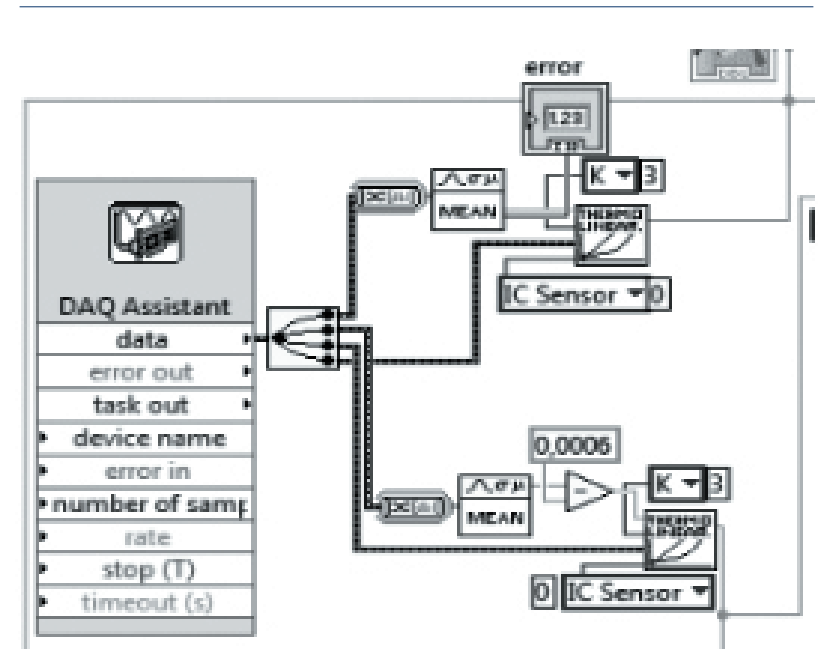

Slika 8. Celina 1 blok dijagrama sa slike 9.

Proces postavljanja novih kuglica odvija se na isti način. Kuglice se ubacuju u odgovarajuća očišćena ležišta na štampanoj ploči, preko njih se postavi prethodno očišćeni čip i uključi se uređaj.

U momentu $t 4$ isključuje se gornji grejač, uključuje se step motor koji podiže fen na odgovarajuću visinu i pritisne se STOP. Nakon što se ohladi štampana ploča, sa prekuglanim čipom, skida se sa uređaja.

Blok dijagram koristi se za unos programskog koda ( $\mathrm{u}$ obliku dijagrama) koji omogućava funkcionisanje virtualnog instrumenta. Na Slici 9 prikazan je blok dijagram virtuelnog instrumenta koji se koristi za kontrolu i praćenje rada stanice. Na dijagramu je, radi preglednosti, posebno označeno pet celina kao njegovi najbitniji delovi.
Celina 1 blok dijagrama, koja je preglednije prikazana na Slici 8 predstavlja funkciju DAQ Assitant, odnosno izgled ikone ove funkcije, na blok dijagramu (nakon što je završena konfiguracija), koja je upotrebljena za konfigurisanje kartice NI-USB-6009. DAQ Assistant je jedna od funkcija iz palete drajvera NI-DAQmx (Data Aquisition). Kartica se koristi za akviziciju podataka o temperaturama donjeg i gornjeg grejača. Pored kreiranja kanala za prenos podataka od termoparova do PC računara, izbora signala, njihovih maksimalnih i minimalnih vrednosti i ostalo, konfiguracijom kartice omogućena je (funkcija TERMO LINEAR na Slici 8) i konverzija vrednosti naponskih signala sa termoparova u odgovarajuće vrednosti temperature. Na taj način se ka PC računaru prosleđuju podaci o temperaturama donjeg i gornjeg grejača stanice. Na ulaz funkcije TERMO LINEAR priključen je IC Sensor (Cold Junction Compensation - kompenzacija hladnih spojeva) koji uklanja efekat napona generisanih hladnim spojevima i time omogućava znatno preciznije merenje temperatura. Vrednosti temperatura koje se dobijaju na izlazima TERMO LINEAR funkcija prosleđuju se ka odgovarajućim indikatorima (grafički prikaz, indikatori sa pokretnom iglom), PID kontrolerima i ostalim delovima blok dijagrama.

Druga i treća celina (Slika 10) blok dijagrama su delovi blok dijagrama koji definišu PID kontrolere za donji i gornji grejač. Podešavanje parametara $(K c, T i$ i $T d)$ PID kontrolera vrši se korišćenjem odgovarajućih kontrola smeštenih na prednjoj ploči virtuelnog instrumenta.

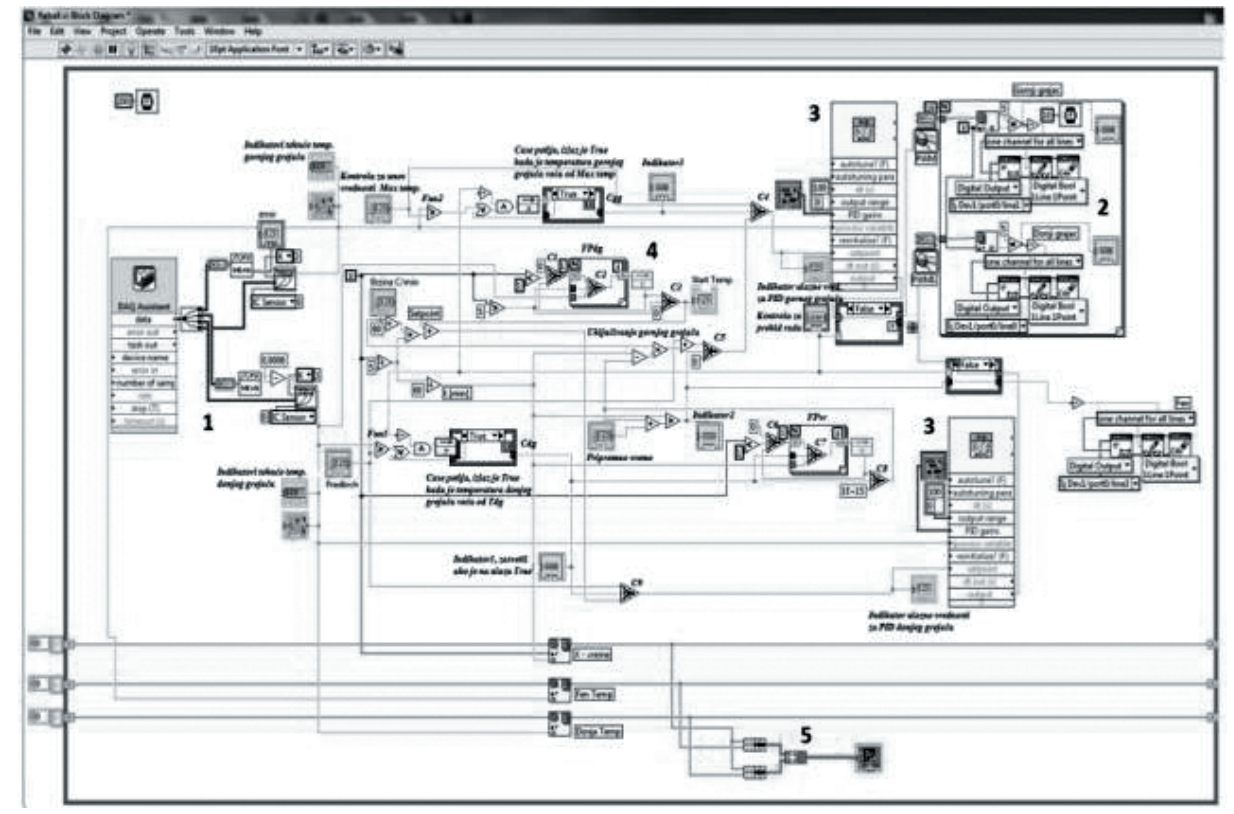

Slika. 9. Blok dijagram virtuelnog instrumenta 


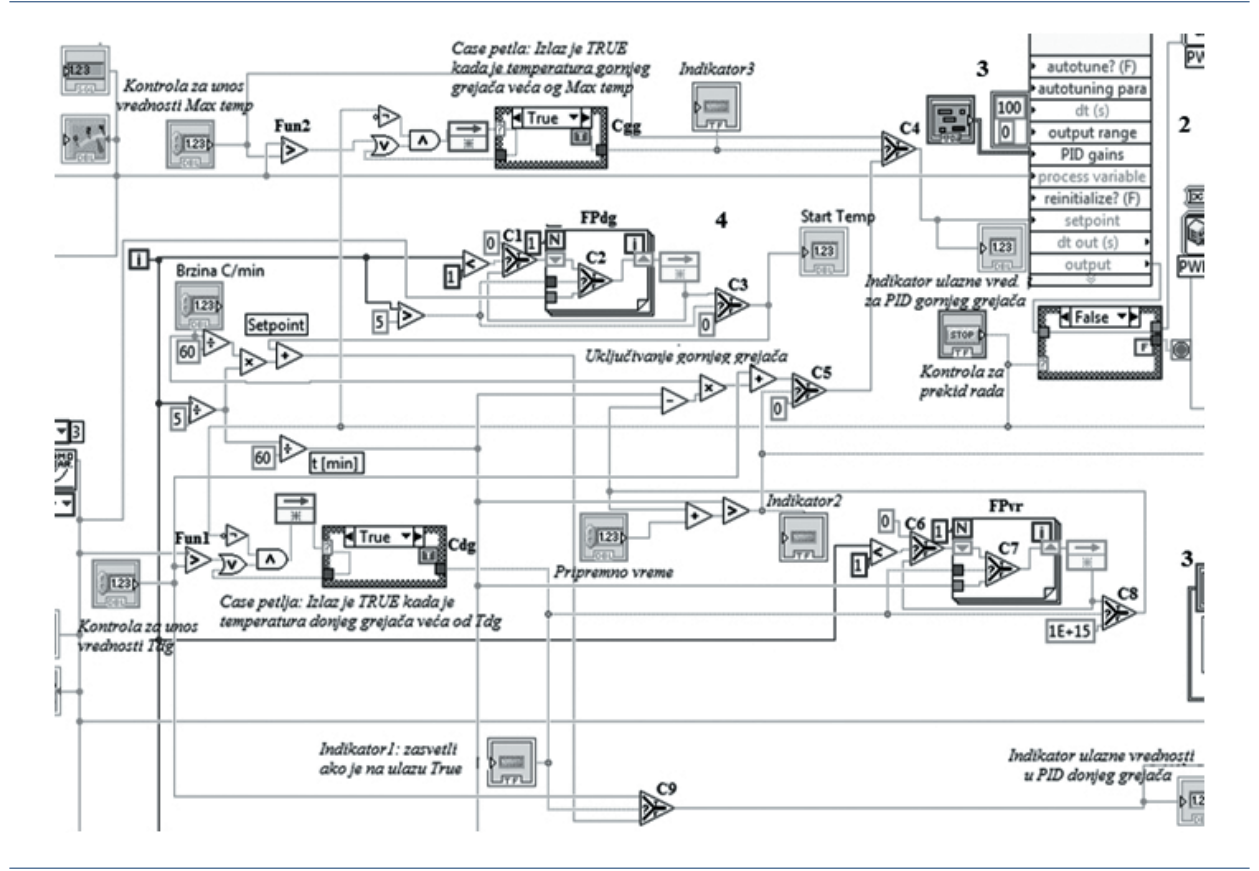

Slika. 10. Deo blok dijagrama sa slike 9, celine 2., 3. i 4.

Celina 4 (Slika 10) na blok dijagramu predstavlja osnovni deo programskog rešenja koji omogućava kontrolu i praćenje uklanjanja i prekuglavanja BGA čipova. Da bi se jednostavnije objasnio princip njegovog funkcionisanja, na ovom delu blok dijagrama su posebno označene dve Case strukture (Cdg - Case struktura donjeg grejača i $C g g$ - Case struktura gornjeg grejača), dve For petlje (FPdg - For peilja donjeg grejača i FPvr - For petlja koja kontroliše Pripremno vreme) i dve funnkcije (Fun1(„>") - upoređuje temperaturu donjeg grejača sa vrednošću Tdg i Fun2 - upoređuje temperaturu gornjeg grejača sa vrednošću Max temp).

Programom je utvrđeno da se gornji grejač uključi dva minuta nakon što donji grejač dostigne temperaturu $T d g$ (u našem slučaju, $140{ }^{\circ} \mathrm{C}$ ). U momentu kada se pokrene program vrednost izlaza Kontrole za prekid rada je True, a na ulaz FTdg pojavljuje se vrednost sobne temperature jer je tog momenta donji grejač na sobnoj temperaturi. Vrednost se potom prosleđuje indikatoru Startna Temp budući da tog momenta selektor $\mathrm{C1}$ propušta ovu vrednost, odnosno signal (posle vremena od $1 \mathrm{~ms}$, propušta samo signale koji dolaze na njegov donji, f-ulaz), tako da na prednoj ploči VI dobijamo informaciju o temperaturi okoline. Kako vreme protiče, temperatura donjeg grejača raste, a funkcija Fun 1 stalno proverava odnos temperature grejača i vrednosti $T d g$. Istovremeno FPdg, koristeći Shift registar i odgovarajuću povratnu funkciju na njenom izlazu, deo izlaznog signala (vrednosti temperature sa izlaza) vraća na ulaz petlje, a deo sabira sa proizvodom vremena i vrednosti kontrole Brzina C/min pri čemu se dobija ukupna temperatura donjeg grejača. Rezultat se prosleđuje na donji ulaz selektora $C 9$. Selektori $C 2$ i $C 3$ za to vreme, ili preciznije, nakon $5 \mathrm{~ms}$ od početka rada, propuštaju signale koji dolaze na njihove gornje t-ulaze.

U trenutku kada temperatura donjeg grejača dostigne vrednost $T d g$ (u ovom slučaju $140^{\circ} \mathrm{C}$, a na Slici 7 t1), funkcija Fun1 na izlazu daje vrednost True što uzrokuje da i izlaz Case petlje $C d g$ takođe dobije vrednost True. Vrednost True se dalje prosleđuje na s-ulaze selektora C7, C8 i C9, kao i na ulaz Indikatora1 što prouzrokuje da, na prednjoj ploči VI, Indikator1 zasvetli stavljajući nam vizuelno do znanja da je temperatura donjeg grejača dostigla vrednost koju smo prethodno uneli u kontrolu Tdg. Vrednost True na s-ulazu selektora C9 omogućava da selektor propusti signal koji dolazi na njegov gornji, t-ulaz, a to je u ovom slučaju vrednost temperature koju smo uneli u kontrolu Tdg. Selektor C9 prosleđuje ovu vrednost na ulaz PID-a za donji grejač, koji tokom daljeg rada, održava temperaturu grejača na vrednost $T d g$. Sa druge strane sada selektori $C 7$ i $C 8$ propuštaju signale koji im dolaze na t-ulaze (selektor C6 propušta signale sa svog t-ulaza samo za vreme od $1 \mathrm{~ms}$ ), što omogućava For petlji FPvr da kontroliše rast vremena od trenutka $t 1$ na dalje.

$\mathrm{U}$ trenutku $t 2$, odnosno posle isteka vremena čija je vrednost uneta u kontroli Pripremno vreme, uključuje se gornji grejač, a FPvr generiše na ulazima Indikatora2 
i selektora C5 vrednosti True. Indikator2 na prednjoj ploči VI zasvetli, a selektor C5 sada propušta signal (vrednosti temperature) koji dolazi na njegov t-ulaz. Vrednost ovog signala jednaka je temperaturi gornjeg grejača. Izlazni signal iz selektora C5 prosleđuje se na donji, s-ulaz selektora C4. Kako je vrednost ovog ulaza False, selektor propušta ovaj signal koji se dalje prosleđuje PID kontroleru za gornji grejač.

Funkcija Fun2 upoređuje tekuću temperaturu gornjeg grejača sa vrednošću koja je uneta u kontrolu Max temp. Onog trenutka kada temperatura gornjeg grejača dostigne vrednost veću od one u kontroli Max temp, na izlazu Case funkcije Cgg generiše se True signal koji se dalje prosleđuje Indikatoru3 (na prednjoj ploči VI Indikator3 zasvetli i upozorava nas da je temperatura gornjeg grejača dostigla vrednost unešenu u kontroli Max temp) i na s-ulaz selektora $C 4$. Budući da je na s-ulazu vrednost True, C4 propušta signal sa njegovog gornjeg, t-ulaza, odnosno vrednost temperature koja je uneta u kontroli Max temp (u našem slučaju, $230^{\circ} \mathrm{C}$ ). PID za gornji grejač, koji prima signal sa izlaza selektora $C 4$, održava ovu temperaturu još oko dva minuta ( $t 4-t 3$, na Slici 7) dok se kalajne kuglice ne istope. a zatim se, pritiskom na dugme STOP, program za praćenje procesa prekida, stanica se isključuje i čip ukljanja sa ploče.

Za sve vreme rada programa, odnosno praćenja procesa uklanjanja čipa sa štampane ploče, na indikatorima tekuće temperature možemo pratiti brojčano i grafički vrednosti temperatura donjeg i gornjeg grejača.

Vizuelna kontrola i praćenje procesa ukljanjanja i prekuglavanja čipova ostvarena je preko grafičke zavisnosti temperatura grejača od vremena. Dobijanje ovih grafika na prednjoj ploči VI realizovano je celinom 5 na blok dijagramu.

\section{EKSPERIMENTALNO SNIMANJE KARAKTERISTIKA UREĐAJA}

Karakteristike stanice za prekuglavanje BGA čipova, koja je opisana u ovom radu, u osnovi obuhvataju zavisnosti temperatura donjeg i gornjeg grejača od vremena na osnovu kojih su, uz pažljivo praćenje promena stanja čipova koji se uklanjaju sa, ili postavljaju na štampanu ploču, utvrđeni optimalni uslovi za rad stanice.

Pri tome se pod optimalnim uslovima podrazumeva da je u toku prekuglavanja čipova neophodno obezbediti da, zbog eventualnog pregrevanja, ne dođe do oštećenja čipova i štampanih ploča, da se u toku postavljanja čipa na štampanu ploču sve kuglice ravnomerno greju i da, zbog neadekvatnog podešavanja temperatura grejača, ne dođe do razlivanja otopljenog lema (kuglica) i pojave kratkih spojeva.

Polazeći od ovih kriterijuma, prethodno su, na osnovu priloženog programskog rešenja, utvrđene (snimljene) zavisnosti temperatura grejača od vremena. Dobijanje grafika realizovano je pri temperaturi okoline od $15,1{ }^{\circ} \mathrm{C}$ i brzini promene temperature donjeg grejača od $25^{\circ} \mathrm{C} / \mathrm{min}$. Maksimalne temperature donjeg i gornjeg grejača postavljene su na $140{ }^{\circ} \mathrm{C}$, odnosno $230^{\circ} \mathrm{C}$ respektivno. Dobijena grafička zavisnost prikazana je na Slici 11 (1 - temperatura donjeg grejača, 2 - temperatura gornjeg grejača). Pri izboru maksimalne temperature donjeg grejača vodili smo računa o tome da na temperaturama od $120{ }^{\circ} \mathrm{C}$ do $160{ }^{\circ} \mathrm{C}$ ne dolazi do oštećenja štampane ploče i ostalih komponenata na njoj. Brzina zagrevanja donjeg greječa podešena je u skladu sa temperaturom okoline (niža temperatura okoline, manja brzina i obrnuto) kako ne bi došlo do eventualnog naprsnuća ploče. Maksimalna temperatura gornjeg grejača podešena je prema temperaturi topljenja lema (kalaja).

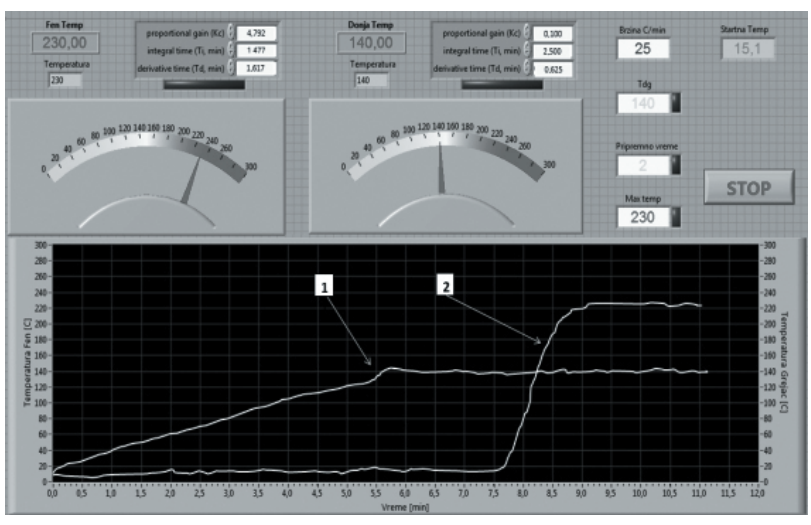

Slika 11. Zavisnost temperature donjeg i gornjeg grejača stanice od vremena-nakon korekcija PID koefijenata donjeg i gornjeg greječa

Takođe, utvrdili smo da je nakon dva minuta od momenta kada temperatura donjeg grejača dostigne vrednost od $140{ }^{\circ} \mathrm{C}$, potrebno uključiti gornji grejač (uključivanje grejača je regulisano programskim kodom). Gornji grejač se znatno brže zagreva i posle 1,5 do 2 min dostiže temperaturu od $230^{\circ} \mathrm{C}$. Na ovoj temperaturi ostaje oko 2 min što je dovoljno da se lem otopi. Nakon toga, oba grejača se isključuju, gornji grejač podiže na određenu visinu i čip uklanja sa štampane ploče.

Na kraju, ukazajemo i na činjenicu da smo stanicu testirali i za realizaciju drugih poslova i utvrdili da se 
primenom LabVIEW softverskog paketa i uređaja koji smo razvili, pored BGA čipova, mogu zalemiti i druge komponente, na primer SMD, što bi u slučaju praktične primene, znatno smanjilo troškove rada i skratilo vreme razvoja proizvoda. Druga oblast u kojoj se može upotrebiti stanica, je proces brze izrade prototipova štampanih ploča, područje gde se danas koriste veliki broj različitih programskih paketa, uređaja i savremenih alata.

\section{ZAKLJUČAK}

Imajući u vidu osobine programskog paketa LabVIEW, mogućnosti personalnih računara i zahteve za prekuglavanjem čipova, u Boru je projektovana stanica za prekuglavanje BGA čipova čiji se rad prati i kontroliše odgovarajućim programskim rešenjem baziranim na okruženju ovog programskog paketa, a koji je opisan i prikazan u ovom radu. Pogodnim izborom vrednosti ulaznih parametara, koji se unose posredstvom prednje ploče, omogućena je izuzetno kvalitetna i precizna kontrola čitavog procesa. U toku eksperimentalnog merenja karakteristika stanice i testiranja rada instalisanih programskih rešenja pokazalo se da je LabVIEW pogodan paket za primenu u ovoj oblasti.

\section{LITERATURA}

[1] https://www.pcmag.com/encyclopedia/term/38577/ bga.

[2] https://en.wikipedia.org/wiki/LabVIEW.

[3] http://www.ni.com/en-rs/shop/labview.html.

[4] Dejan V. Antić, Zoran Stević, Mirjana RajčićVujasinović, "Merenja i akvizicija podataka zasnovana na personalnom računaru," Ifoth-Jahorina, Mart 2007.

[5] Pavel Kovač, Marin Gostimirović, Milenko Sekulić, Borislav Savković, "Programsko i tehničko rešenje virtualne instrumentacije za merenje otpora rezanja pri čeonom glodanju", Fakultet tehničkih nauka Novi Sad, 2010.

[6] Hans-Petter Halvorsen, "Data Acquisition," University College of Southeast Norway, 2016.

[7] http://www.ni.com/pdf/manuals/375296a.pdf.

[8] http://www.mdpi.com/1424-8220/8/3/1819/htm, Zoran Stević *, Zoran Andjelković and Dejan Antić, A New PC and LabVIEW Package Based System for Electrochemical Investigations, Sensors 2008, 8(3), 1819-1831.

[9] https://sh.wikipedia.org/wiki/Kalaj. 